\title{
Pengaruh Dosis Pupuk NPK dan Pemangkasan Tunas Lateral terhadap Pertumbuhan dan Hasil Tanaman Semangka (Citrullus vulgaris Schard)
}

\author{
The Dose Effect of NPK Fertilizer and Pruning of Watermelon Lateral Shoots \\ on Growth and Plant Result (Citrullus vulgaris Schard)
}

\author{
Azzura $^{1}$, Bakhtiar ${ }^{1}$ dan Nanda Mayani ${ }^{{ }^{*}}$ \\ ${ }^{1}$ Program Studi Agroteknologi, Fakultas Pertanian, Universitas Syiah Kuala
}

\begin{abstract}
Abstrak. Salah satu teknik budidaya untuk mendapatkan hasil semangka yang baik adalah dengan pemupukan yang tepat dan pemangkasan. Jenis pupuk anorganik yang digunakan dalam budidaya tanaman semangka adalah pupuk NPK Majemuk. Sementara pemangkasan adalah suatu kegiatan membuang bagian tanaman yaitu bagian pucuk, cabang atau ranting tanaman sehingga terjadi penimbunan karbohidrat, protein dan hormon yang merangsang keluarnya bunga dan buah. Penelitian dilaksanakan di Desa Paloh Jeureula, Kecamatan Sakti Kabupaten Pidie dan Laboratorium Hortikultura Fakultas Pertanian Universitas Syiah Kuala yang berlangsung dari bulan September sampai November 2017. Penelitian ini menggunakan Rancangan Acak Kelompok (RAK) pola faktorial yang terdiri dari 4 perlakuan dosis pupuk NPK dan 2 perlakuan pemangkasan yang diulang sebanyak 3 kali sehingga terdapat 8 kombinasi perlakuan yang terdiri dari 24 unit percobaan dengan 6 sampel untuk setiap unit percobaan. Hasil penelitian menunjukkan bahwa dosis pupuk NPK yang tepat untuk pertumbuhan dan hasil tanaman semangka yaitu $160 \mathrm{~g} /$ tanaman, sementara pemangkasan tunas yang terbaik untuk pertumbuhan dan hasil tanaman semangka yaitu pemangkasan tunas lateral. Kombinasi perlakuan yang terbaik untuk pertumbuhan dan hasil tanaman semangka yaitu dosis pupuk NPK $160 \mathrm{~g} /$ tanaman dengan pemangkasan tunas lateral.
\end{abstract}

Kata kunci : Pupuk, NPK, Majemuk, Pemangkasan, Lateral, Pertumbuhan, Hasil.

Abstract. The low production of red pepper plants in Indonesia is partly caused by disease attacks and unavailability of high quality seeds or have low viability. Biological Seed Treatment using rhizobacteria is one of the innovations developed for disease control and growth of plants. This research has been carried out in Agricultural Science and Technology Laboratory of Agrotechnology Study Program Faculty of Agriculture Unsyiah. The study was conducted from May to July 2017. This study used a Completely Randomized Design (RAL) of non factorial pattern in experiment I consisted of 18 treatments repeated 3 times so that each of 54 experiments on pathogenic Phytophthora capsici and 54 units of experiments was obtained pathogen Colletotrichum capsici to obtain 108 total unit of experiment. In the second experiment using Completely Randomized Design (RAL) the factorial pattern consisted of 19 rizobacterial treatments and 2 repeated treatments of varieties 2 times. Thus there were 38 treatment combinations consisting of 48 experimental units with 25 plant units in each treatment. The result of experiment I showed that isolate SRK 5 (1) from Serulee Kayu Village, Bukit Subdistrict, Bener Meuriah Regency was able to suppress the growth of $C$. capsici pathogens with $82.22 \%$ inhibition and against $P$. capsici $71.11 \%$. The results of experiment II showed that rizobakteri effective as plant growth enhancer (RPPT) to germination process of red chilli seedlings in increasing seed viability and vigor to maximum growth potential and germination is isolate KTK 8 (5) where the varieties of PM999 is better than Taro varieties, but the different isolates of SRK 5 (1), HWI 4 (1) and BS3 5 (3) were able to increase the vigor index on higher Taro varieties compared to the PM999 varieties. While 
the effect of rizobacterial treatment on the growth of red chili seedlings has not shown a significant increase in the two varieties tested.

Key words : Fertilizer, NPK, Compound, Pruning, Lateral, Growth, Result.

\section{PENDAHULUAN}

Tanaman semangka merupakan salah satu komoditas hortikultura dari famili labulabuan (Cucurbitaceae) yang mempunyai nilai ekonomi cukup tinggi. Buah semangka yang berkualitas baik dapat dihasilkan melalui modifikasi teknik budidaya yang intensif. Salah satu teknik yang dilakukan untuk menghasilkan semangka yang baik adalah dengan pemupukan yang tepat dan pemangkasan tunas lateral. Pemupukan adalah pemberian bahan berupa pupuk atau bahan-bahan lain seperti bahan organik, bahan kapur, pasir ataupun tanah liat ke dalam tanah yang bertujuan untuk menambahkan unsur hara ke dalam tanah (Hasibuan, 2006).

Pupuk digolongkan menjadi dua jenis yaitu pupuk organik dan pupuk anorganik. Pupuk organik adalah pupuk yang berasal dari semua sisa bahan tanaman, pupuk hijau dan kotoran hewan yang memiliki kandungan unsur hara yang rendah. Pemberian pupuk organik dapat meningkatkan produktivitas tanah karena bahan organik memiliki kemampuan untuk memperbaiki sifat kimia, fisika maupun biologi tanah. Sedangkan pupuk anorganik memiliki kelebihan dalam memenuhi sifat kimia tanah seperti penambahan unsur hara yang tersedia di dalam tanah lebih cepat. Pupuk anorganik yang biasa digunakan dalam budidaya tanaman adalah pupuk NPK majemuk, Urea, TSP, KCl dan lain-lain (Suwahyono dan Untung, 2011).

Upaya peningkatan produksi terus dilakukan, tindakan yang bisa dilakukan diantaranya adalah dengan memanipulasi pertumbuhan. Dewani (2000) menyatakan bahwa upaya peningkatan produksi semangka dapat dilakukan dengan cara meningkatkan teknik budidaya, salah satunya yaitu memanipulasi pertumbuhan (pemangkasan). Pemangkasan adalah suatu kegiatan melukai dan membuang bagian tanaman yaitu bagian pucuk, cabang atau ranting tanaman sehingga terjadi penimbunan karbohidrat, protein dan hormon yang dapat merangsang keluarnya bunga dan buah. Wartapa et al. (2009) juga menyatakan pemangkasan adalah salah satu cara dalam memacu pertumbuhan, dari perombakan timbunan karbohidrat yang dicadangkan untuk pertumbuhan generatif, namun dipergunakan untuk pembentukan tunas maupun pembentukan bunga.

Junaidi et, al (2013) menyatakan bahwa pengaruh utama pemangkasan menunjukkan bahwa penanaman semangka dengan cara tanpa dipangkas tidak berpengaruh nyata terhadap peningkatan berat buah di banding dengan dilakukan pemangkasan. Berdasarkan uraian diatas maka perlu dilakukan penelitian tentang pengaruh dosis pupuk NPK dan pemangkasan tunas lateral terhadap pertumbuhan dan hasil tanaman semangka (Citrullus vulgaris Schard).

\section{Tempat dan Waktu Penelitian}

\section{METODE PENELITIAN}

Penelitian ini dilaksanakan di Desa Paloh Jeureula, kecamatan Sakti kabupaten Pidie dan Laboratorium Hortikultura Fakultas Pertanian Universitas Syiah Kuala yang berlangsung dari bulan September sampai November 2017.

\section{Alat dan Bahan Penelitian}

Alat yang digunakan dalam penelitian ini adalah cangkul, parang, sekop, garu, pisau, ember, meteran, tali, kereta sorong, gembor, timbangan, sprayer, kertas label, alat tulis, kalkulator, lembar pencatatan data dan kamera. Sedangkan bahan yang digunakan dalam penelitian ini adalah benih semangka varietas Dende Inges (10 g), pupuk NPK Phonska (15:15:15) (21,6 $\mathrm{kg}$ ), pupuk kandang (720 kg), Mulsa Plastik Hitam Perak (MPHP) dengan panjang 125 meter, insektisida virtaco dan polibag kecil untuk pembibitan (350 polibag). 


\section{Rancangan Penelitian}

Penelitian ini dilakukan dengan menggunakan Rancangan Acak Kelompok (RAK) pola faktorial dengan 4 perlakuan dosis pupuk NPK (D), yaitu: $\mathrm{D}_{0}=$ Kontrol, $\mathrm{D}_{1}=80$ $\mathrm{g} / \operatorname{tanaman}(320 \mathrm{~kg} / \mathrm{ha}), \mathrm{D}_{2}=120 \mathrm{~g} / \operatorname{tanaman}(480 \mathrm{~kg} / \mathrm{ha}), \mathrm{D}_{3}=160 \mathrm{~g} / \operatorname{tanaman}(640 \mathrm{~kg} / \mathrm{ha})$, dan 2 perlakuan pemangkasan tunas lateral $(\mathrm{P})$, yaitu: $\mathrm{P}_{0}=$ Tanpa pemangkasan, $\mathrm{P}_{1}=$ Pemangkasan. Secara keseluruhan terdapat 8 kombinasi perlakuan dengan 3 kali ulangan, sehingga diperoleh 24 satuan percobaan. Setiap satuan percobaan terdapat 10 tanaman dengan 6 tanaman merupakan tanaman sampel.

\section{Analisis Data Penelitian}

Data hasil pengamatan pada setiap peubah dianalisis dengan anova. Data yang menunjukkan perbedaan yang nyata pada Fhitung maka dilanjutkan dengan Uji Beda Nyata Jujur(BNJ) pada taraf 0,05

\section{Prosedur Penelitian \\ Persiapan Benih}

Benih semangka yang digunakan dalam penelitian adalah semangka kuning hibrida Dende Inges. Semangka kuning hibrida Dende Inges yang diproduksi oleh AURA seed. Benih yang digunakan sebanyak 10 gram.

\section{Pembibitan}

Pembibitan dilakukan dalam polibag kecil yang terlebih dahulu diisi dengan media tanah dan pupuk kandang dengan perbandingan 3:1. Setiap polybag diisi dengan 1 benih semangka. Pembibitan diletakkan di tempat yang teduh dan lama pembibitan selama 15 hari setelah persemaian.

\section{Persiapan Lahan}

Lahan yang digunakan pada penelitian ini adalah tanah sawah yang terlebih dahulu dibuat bedengan dengan ukuran panjang $300 \mathrm{~cm}$, lebar $500 \mathrm{~cm}$ dan jarak antar bedeng $50 \mathrm{~cm}$. Pinggir bedengan dibuat lebih tinggi $10 \mathrm{~cm}$, kemudian digemburkan terlebih dahulu dengan tujuan tanaman semangka yang ditanam dapat tumbuh dengan sempurna.

\section{Pemberian Pupuk Kandang}

Pemupukan dasar dilakukan 7 hari sebelum penarikan mulsa. Pupuk dasar yang diberikan adalah pupuk kandang dengan dosis 20 ton/ha (30 kg/bedeng). Pupuk kandang diberikan secara merata pada bagian pinggir bedengan dengan lebar $90 \mathrm{~cm}$ dari drainase. Pemberian pupuk kandang selain untuk memperbaiki sifat fisik dan kimia tanah juga bertujuan sebagai penyedia unsur hara mikro bagi tanaman. Dengan diberikan pupuk kandang, maka pertumbuhan tanaman pada saat pindah tanam tidak terjadi stagnan.

\section{Pemberian Pupuk NPK Phonska}

Pupuk NPK Phonska diberikan 2 hari sebelum pemasangan mulsa. Pupuk diberikan dalam satu tahap dari dosis perlakuan. Pupuk diberikan dengan cara ditabur di seluruh permukan tanah yang telah ditinggikan, kemudian digaru agar pupuk tercampur dengan tanah.

\section{Pemasangan Mulsa}

Mulsa yang digunakan adalah jenis Mulsa Plastik Hitam Perak (MPHP) 5 kg dengan merek dagang cap Panda. Mulsa memiliki ukuran lebar $90 \mathrm{~cm}$ dengan panjang 125 meter. Pemasangan mulsa dilakukan pada siang hari agar mempermudah dalam penarikan. Mulsa dipotong 1 meter kurang dari ukuran panjang bedeng dan dijemur selama 20 menit agar lebih 
elastis. Setiap sisi bedeng dipasangkan penjepit dengan jarak 1 meter, guna mencegah mulsa terangkat oleh angin.

\section{Pembuatan Lubang Tanam}

Lubang tanam dibuat 3 hari sebelum bibit pindah tanam. Jarak tanam semangka adalah $60 \mathrm{~cm}$ dalam barisan. Pelubangan mulsa dilakukan dengan kaleng susu yang telah dipanaskan. Buat lubang tanam dengan kedalaman 3-5 cm. Pembuatan lubang tanam dengan menggunakan tugal kayu yang berdiameter $5 \mathrm{~cm}$. Dalam setiap bedengan terdapat 10 lubang tanam, dengan masing-masing sisi terdapat 5 lubang tanam.

\section{Penanaman}

Penanaman dilakukan waktu umur bibit 15 hari setelah semai dengan ciri-ciri sudah memiliki 2-3 helai daun. Bibit yang digunakan untuk penanaman adalah bibit yang pertumbuhannya kuat dan tegak. Setiap lubang tanam ditanam satu tanaman, sehingga dalam satu bedengan terdapat 10 tanaman.

\section{Pemeliharaan}

Pemeliharaan tanaman meliputi penyiraman, penyulaman, pengendalian gulma serta pengendalian hama dan penyakit.

- Penyiraman

Penyiraman dilakukan setiap hari yaitu pada pagi hari dan sore hari atau disesuaikan dengan keadaan cuaca. Penyiraman dilakukan dengan menggunakan gembor.

- Penyulaman

Tanaman yang mati atau pertumbuhan yang abnormal dilakukan pemyulaman. Bibit yang digunakan adalah bibit yang ada di tempat pembibitan dan dilakukan pada tanaman berumur 7 HST.

- Pengendalian gulma

Pengendalian gulma dilakukan dengan cara fisik atau mekanis. Gulma yang tumbuh di sekitar lubang tanam, maka pengendaliannya dengan cara dicabut.

- Pengendalian hama dan penyakit

Hama yang menyerang tanaman semangka adalah belalang dan ulat, pengendaliannya dengan menggunakan insektisida. Insektisida yang digunakan adalah insektisida Virtaco 300 SC dengan bahan aktif Klorantraniliprol 100 gram/L + Tiametoksam 200 gram/L.

\section{Pemangkasan}

Pemangkasan dilakukan pada saat tanaman sudah berumur 19 HST. Tanaman yang merupakan perlakuan, semua tunas yang tumbuh dipotong kecuali 2 tunas yang tumbuh diawal. Alat yang digunakan untuk pemangkasan adalah pisau dan tunas dipotong $2 \mathrm{~cm}$ dari ketiak daun tempat tumbuh tunas.

\section{Pemanenan}

Pemanenan dilakukan pada umur 55 HST dengan ciri-ciri sulur yang terdapat pada ketiak daun tempat melekatnya tangkai buah sudah mengering. Pemanenan dilakukan dengan cara memotong tangkai buah menggunakan pisau.

\section{Parameter Pengamatan}

Parameter yang diamati dalam penelitian ini adalah sebagai berikut: Panjang tanaman dan Jumlah daun umur 15, 30, 45 dan 55 HST, Umur berbunga, Panjang buah, Diameter buah dan Berat buah.

\section{HASIL DAN PEMBAHASAN}




\section{Pengaruh Perlakuan Dosis Pupuk NPK terhadap Pertumbuhan dan Hasil Tanaman Semangka}

Hasil uji $\mathrm{F}$ pada analisis ragam menunjukkan bahwa dosis pupuk NPK berpengaruh sangat nyata terhadap panjang tanaman dan jumlah daun umur 15, 30, 45 dan 55 HST, umur berbunga, panjang buah, diameter buah dan berat buah.

Tabel 1. Rata-rata Nilai Pertumbuhan Tanaman Semangka Akibat Perlakuan Dosis Pupuk NPK

\begin{tabular}{lcccccccc}
\hline \multirow{2}{*}{$\begin{array}{c}\text { Dosis Pupuk } \\
\text { NPK }\end{array}$} & \multicolumn{9}{c}{ Panjang Tanaman } & \multicolumn{4}{c}{ Jumlah Daun } \\
\cline { 2 - 9 } & 15 HST & 30 HST & 45 HST & 55 HST & 15 HST & 30 HST & 45 HST & 55 HST \\
\hline Kontrol & $36,60 \mathrm{a}$ & $107,50 \mathrm{a}$ & $161,17 \mathrm{a}$ & $201,67 \mathrm{a}$ & $13 \mathrm{a}$ & $62,67 \mathrm{a}$ & $77,33 \mathrm{a}$ & $102,33 \mathrm{a}$ \\
$80 \mathrm{~g} / \mathrm{tan}$ & $78,50 \mathrm{~b}$ & $205,50 \mathrm{~b}$ & $299,33 \mathrm{~b}$ & $344,50 \mathrm{~b}$ & $25,17 \mathrm{~b}$ & $109,00 \mathrm{~b}$ & $158,00 \mathrm{~b}$ & $179,00 \mathrm{~b}$ \\
$120 \mathrm{~g} / \mathrm{tan}$ & $97,34 \mathrm{c}$ & $263,50 \mathrm{c}$ & $372,17 \mathrm{c}$ & $423,50 \mathrm{c}$ & $32,17 \mathrm{c}$ & $134,67 \mathrm{c}$ & $195,33 \mathrm{c}$ & $237,67 \mathrm{c}$ \\
$160 \mathrm{~g} / \tan$ & $109,67 \mathrm{~d}$ & $289,84 \mathrm{c}$ & $391,50 \mathrm{c}$ & $444,00 \mathrm{c}$ & $35,67 \mathrm{~d}$ & $152,00 \mathrm{~d}$ & $249,33 \mathrm{~d}$ & $285,33 \mathrm{~d}$ \\
\hline BNJ 0,05 & 10,50 & 29,53 & 32,99 & 25,03 & 2,4 & 11,66 & 17,66 & 21,03 \\
\hline
\end{tabular}

Keterangan: Angka yang diikuti oleh huruf yang sama pada kolom yang sama berbeda tidak nyata pada Uji Beda Nyata Jujur (BNJ) $\alpha=0,05$

Tabel 2. Rata-rata Nilai Hasil Tanaman Semangka Akibat Perlakuan Dosis Pupuk NPK

\begin{tabular}{ccccc}
\hline Dosis Pupuk & \multicolumn{4}{c}{ Peubah } \\
\cline { 2 - 5 } NPK & Umur Berbunga (hari) & Panjang Buah $(\mathrm{cm})$ & Diameter Buah $(\mathrm{cm})$ & Berat Buah $(\mathrm{kg})$ \\
\hline Kontrol & $21,00 \mathrm{a}$ & $14,08 \mathrm{a}$ & $10,92 \mathrm{a}$ & $1,00 \mathrm{a}$ \\
$80 \mathrm{~g} / \mathrm{tan}$ & $24,30 \mathrm{~b}$ & $16,17 \mathrm{~b}$ & $11,59 \mathrm{a}$ & $1,40 \mathrm{~b}$ \\
$120 \mathrm{~g} / \mathrm{tan}$ & $27,00 \mathrm{c}$ & $17,75 \mathrm{~b}$ & $12,51 \mathrm{~b}$ & $1,68 \mathrm{c}$ \\
$160 \mathrm{~g} / \mathrm{tan}$ & $27,17 \mathrm{c}$ & $22,83 \mathrm{c}$ & $12,81 \mathrm{~b}$ & $2,10 \mathrm{~d}$ \\
BNJ 0,05 & 1,53 & 1,84 & 0,77 & 0,17 \\
\hline
\end{tabular}

Keterangan: Angka yang diikuti oleh huruf yang sama pada kolom yang sama berbeda tidak nyata pada Uji Beda Nyata Jujur (BNJ) $\alpha=0,05$

Hasil analisis ragam (Uji F) menunjukkan bahwa dosis pupuk NPK yang tepat untuk pertumbuhan dan hasil tanaman semangka yaitu $160 \mathrm{~g} /$ tanaman. Pernyataan Sutedjo (2002), unsur $\mathrm{N}$ yang terkandung dalam pupuk NPK berfungsi untuk meningkatkan pertumbuhan vegetatif tanaman sehingga panjang tanaman akan meningkat sejalan dengan pertambahan ukuran ruas. Sedangkan unsur $\mathrm{P}$ berfungsi sebagai mempercepat proses diferensiasi sel. Rahim dan Sukarni (2011) menyatakan bahwa unsur K berfungsi membantu proses fotosintesis untuk pembentukan senyawa organik yang diangkut ke organ tempat penimbunan, dalam hal ini adalah buah semangka.

\section{Pengaruh Perlakuan Pemangkasan Tunas Lateral terhadap Pertumbuhan dan Hasil Tanaman Semangka}

Hasil uji $\mathrm{F}$ pada analisis ragam menunjukkan bahwa pemangkasan tunas lateral berpengaruh sangat nyata terhadap panjang tanaman umur 30 dan 55 HST, jumlah daun umur 30, 45 dan 55 HST, diameter buah dan berat buah, berpengaruh nyata terhadap panjang tanaman umur 45 HST, namun berpengaruh tidak nyata terhadap panjang tanaman 15 HST, jumlah daun umur 15 HST, umur berbunga dan panjang buah.

Tabel 3. Rata-rata Nilai Pertumbuhan Tanaman Semangka Akibat Perlakuan Pemangkasan Tunas Lateral

\begin{tabular}{lcccccccc}
\hline \multirow{2}{*}{$\begin{array}{l}\text { Pemangkasan } \\
\text { Tunas Lateral }\end{array}$} & \multicolumn{3}{c}{ Panjang Tanaman $(\mathrm{cm})$} & \multicolumn{4}{c}{ Jumlah Daun (helai) } \\
\cline { 2 - 9 } & 15 HST & 30 HST & 45 HST & 55 HST & 15 HST & 30 HST & 45 HST & 55 HST \\
\hline Tanpa & 80,42 & 205,75 & 292,75 & 342,08 & 26 & 134,42 & 204,17 & 234,17 \\
Pemangkasan & & $\mathrm{a}$ & $\mathrm{a}$ & $\mathrm{a}$ & & $\mathrm{b}$ & $\mathrm{b}$ & $\mathrm{b}$ \\
Pemangkasan & 80,59 & 227,42 & 316,33 & 364,75 & 27 & 92,75 & 135,87 & 168,00 \\
& & $\mathrm{~b}$ & $\mathrm{~b}$ & $\mathrm{~b}$ & & $\mathrm{a}$ & $\mathrm{a}$ & $\mathrm{a}$ \\
\hline \hline
\end{tabular}

Corresponding author: bakhtiar_fp@unsyiah.ac.id

JIM Pertanian Unsyiah - AGT, Vol. 3, No. 2, Mei 2018: 1-8 
Keterangan: Angka yang diikuti oleh huruf yang sama pada kolom yang sama berbeda tidak nyata pada Uji Beda Nyata Jujur (BNJ) $\alpha=0,05$

Tabel 4. Rata-rata Nilai Hasil Tanaman Semangka Akibat Perlakuan Pemangkasan Tunas Lateral

\begin{tabular}{lcccc}
\hline Pemangkasan & \multicolumn{4}{c}{ Peubah } \\
\cline { 2 - 5 } Tunas Lateral & Umur Berbunga (hari) & Panjang Buah $(\mathrm{cm})$ & Diameter Buah $(\mathrm{cm})$ & Berat Buah $(\mathrm{kg})$ \\
\hline Tanpa & 25,25 & 17,25 & $11,68 \mathrm{a}$ & $1,41 \mathrm{a}$ \\
Pemangkasan & & 18,17 & $12,23 \mathrm{~b}$ & $1,68 \mathrm{~b}$ \\
Pemangkasan & 24,50 & - & 4,01 & 0,09 \\
\hline BNJ 0,05 & - & &
\end{tabular}

Keterangan: Angka yang diikuti oleh huruf yang sama pada kolom yang sama berbeda tidak nyata pada Uji Beda Nyata Jujur (BNJ) $\alpha=0,05$

Hasil analisis ragam (Uji F) menunjukkan bahwa perlakuan pemangkasan yang terbaik untuk pertumbuhan dan hasil tanaman semangka dijumpai pada pemangkasan tunas lateral . Harjadi et al. (2010) menyatakan pemangkasan bertujuan untuk meningkatkan hasil dengan cara fotosintat ditranslokasikan untuk pembentukan buah. Produksi yang tinggi akan diperoleh bila seluruh proses berjalan lancar dan seimbang. Sutedjo (2002) menambahkan bahwa pemangkasan ini dilakukan pada batang, daun, dan organ vegetatif lainnya yang akan memanfaatkan hasil fotosintat dari daun. Semakin sedikit bagian tanaman yang memanfaatkan maka seluruh hasil fotosintat akan ditranslokasikan ke organ yang lebih produktif.

\section{Pengaruh Interaksi antara Perlakuan Dosis Pupuk NPK dan Pemangkasan terhadap Pertumbuhan dan Hasil Tanaman Semangka}

Hasil uji $\mathrm{F}$ pada analisis ragam menunjukkan bahwa terdapat interaksi antara dosis pupuk NPK dengan pemangkasan tunas lateral. Interaksi antara dosis pupuk NPK dengan pemangkasan tunas lateral berpengaruh sangat nyata terhadap jumlah daun umur 30, 45 dan 55 HST dan berpengaruh nyata terhadap berat buah, namun berpengaruh tidak nyata terhadap panjang tanaman umur 15, 30, 45 dan 55 HST, jumlah daun umur 15 HST dan umur berbunga.

Tabel 5. Nilai rata-rata jumlah daun umur 30 HST akibat intaraksi antara dosis pupuk NPK dengan pemangkasan tunas lateral

\begin{tabular}{lcc}
\hline \multicolumn{1}{c}{ Perlakuan } & $\begin{array}{c}\text { Tanpa } \\
\text { Pemangkasan }\end{array}$ & Pemangkasan \\
\hline Kontrol & $70,76 \mathrm{aA}$ & $54,67 \mathrm{aA}$ \\
$80 \mathrm{~g} /$ tanaman & $128,33 \mathrm{bB}$ & $89,67 \mathrm{bA}$ \\
$120 \mathrm{~g} /$ tanaman & $162,67 \mathrm{cB}$ & $106,67 \mathrm{bcA}$ \\
$160 \mathrm{~g} /$ tanaman & $184,00 \mathrm{~dB}$ & $120,00 \mathrm{cA}$ \\
\hline BNJ 0,05 & & 20,02 \\
\hline Keterangan : Angka yang diikuti oleh huruf yang sama berbeda tidak nyata pada taraf 0,05 (Uji BNJ). Huruf kecil dibaca
\end{tabular}

Tabel 6. Nilai rata-rata jumlah daun umur 45 HST akibat intraksi antara dosis pupuk NPK dengan pemangkasan tunas lateral

\begin{tabular}{lcc}
\hline \multicolumn{1}{c}{ Perlakuan } & Tanpa & Pemangkasan \\
& Pemangkasan & $71,67 \mathrm{aA}$ \\
Kontrol & $83,00 \mathrm{aA}$ & $125,33 \mathrm{bA}$ \\
$80 \mathrm{~g} /$ tanaman & $190,67 \mathrm{bB}$ & $157,33 \mathrm{cA}$ \\
$120 \mathrm{~g} /$ tanaman & $233,33 \mathrm{cB}$ & $189,00 \mathrm{dA}$ \\
\hline $160 \mathrm{~g} /$ tanaman & $309,67 \mathrm{~dB}$ & \\
\hline BNJ 0,05 & & 30,32 \\
\hline
\end{tabular}


Keterangan : Angka yang diikuti oleh huruf yang sama berbeda tidak nyata pada taraf 0,05 (Uji BNJ). Huruf kecil dibaca vertikal dan huruf besar dibaca horizontal

Tabel 7. Nilai rata-rata jumlah daun umur 55 HST akibat interaksi antara dosis pupuk NPK dengan pemangkasan tunas lateral

\begin{tabular}{lcc}
\hline \multicolumn{1}{c}{ Perlakuan } & $\begin{array}{c}\text { Tanpa } \\
\text { Pemangkasan }\end{array}$ & Pemangkasan \\
\hline Kontrol & $111,67 \mathrm{aA}$ & $93 \mathrm{aA}$ \\
$80 \mathrm{~g} /$ tanaman & $214,33 \mathrm{bB}$ & $143,67 \mathrm{bA}$ \\
$120 \mathrm{~g} / \operatorname{tanaman}$ & $266,67 \mathrm{cB}$ & $206,67 \mathrm{cA}$ \\
$160 \mathrm{~g} / \operatorname{tanaman}$ & $342,00 \mathrm{~dB}$ & $228,67 \mathrm{cA}$ \\
\hline BNJ 0,05 & 36,11 \\
\hline \multicolumn{2}{l}{ Keterangan : Angka yang diikuti oleh huruf yang sama berbeda tidak nyata pada taraf 0,05 (Uji BNJ). Huruf kecil dibaca } \\
\multicolumn{2}{l}{ vertikal dan huruf besar dibaca horizontal }
\end{tabular}

Tabel 8. Nilai rata-rata berat buah akibat interaksi antara dosis pupuk NPK dan pemangkasan tunas lateral

\begin{tabular}{lcc}
\hline \multicolumn{1}{c}{ Perlakuan } & $\begin{array}{c}\text { Tanpa } \\
\text { Pemangkasan }\end{array}$ & Pemangkasan \\
\hline Kontrol & $0,87 \mathrm{aA}$ & $1,13 \mathrm{aA}$ \\
$80 \mathrm{~g} /$ tanaman & $1,35 \mathrm{bA}$ & $1,45 \mathrm{bA}$ \\
$120 \mathrm{~g} / \mathrm{tanaman}$ & $1,57 \mathrm{bA}$ & $1,78 \mathrm{cA}$ \\
$160 \mathrm{~g} /$ tanaman & $1,87 \mathrm{cA}$ & $2,33 \mathrm{~dB}$ \\
\hline BNJ 0,05 & 0,28 \\
\hline \multicolumn{2}{l}{ Keterangan : Angka yang dikuti oleh huruf yang sama berbeda tidak nyata pada taraf 0,05 (Uji BNJ). Huruf kecil dibaca } \\
\multicolumn{2}{l}{ vertikal dan huruf besar dibaca horizontal }
\end{tabular}

Hasil analisis ragam (Uji F) menunjukkan bahwa interaksi antara perlakuan dosis pupuk NPK dan pemangkasan tunas lateral yang terbaik pada dosis pupuk NPK 160 $\mathrm{g} /$ tanaman dan pemangkasan tunas lateral. Syah et al. (2016) menyatakan bahwa jumlah daun menjadi meningkat akibat pemberian pupuk NPK dengan dosis $700 \mathrm{~kg} / \mathrm{ha}$ dibandingkan dengan pemberian pupuk NPK dengan dosis $350 \mathrm{~kg} / \mathrm{ha}$. Namun apabila dikombinasikan dengan pemangkasan tunas lateral malah dapat menyebabkan jumlah daun menjadi menurun dibandingkan dengan perlakuan tanpa pemangkasan tunas lateral. Hal ini dikarenakan setelah dilakukan pemangkasan tunas lateral maka jumlah percabangan hanya akan tersisa 2 cabang, sehingga jumlah daun juga ikut menurun. Susiani (2003) menyatakan bahwa pada tanaman labu mie (Cucurbita pepo L) perlakuan tanpa pemangkasan menghasilkan jumlah daun yang lebih tinggi dibandingkan dengan perlakuan pemangkasan.

Hasil penelitian Jasmine et al. (2015) peningkatan dosis pupuk NPK menghasilkan berat perbuah mengalami peningkatan. Hasil tersebut menunjukkan bahwa semakin ditambah dosis pupuk NPK yang diberikan maka dapat meningkatkan berat buah semangka. Peningkatan dosis pupuk NPK saja belum cukup untuk meningkatkan berat buah semangka, maka harus dilakukan pemangkasan tunas lateral agar menghasilkan berat buah yang lebih tinggi dibandingkan dengan tanpa pemangkasan tunas lateral. Tripama (2009) menyatakan bahwa dengan menyisakan 2 cabang dan pengolahan tanah menghasilkan berat buah dan diameter panjang buah yang paling tinggi dibandingkan perlakuan lainnya.

\section{KESIMPULAN}

Dosis pupuk NPK berpengaruh sangat nyata terhadap panjang tanaman dan jumlah daun umur 15, 30, 45 dan 55 HST, umur berbunga dan berat buah segar. Dosis pupuk NPK terbaik dijumpai pada $160 \mathrm{~g} /$ tanaman. Pemangkasan tunas lateral berpengaruh sangat nyata terhadap panjang tanaman umur 30 dan 55 HST, jumlah daun umur 30, 45 dan 55 HST, berat buah, berpengaruh nyata terhadap peubah panjang tanaman umur 45 HST, namun berpengaruh tidak nyata terhadap panjang tanaman 15 HST, jumlah daun umur 15 HST dan 
umur tanaman berbunga. Pemangkasan terbaik dijumpai pada pemangkasan tunas lateral. Terdapat interaksi antara dosis pupuk NPK dengan pemangkasan tunas lateral yang berpengaruh sangat nyata terhadap jumlah daun umur 30, 45 dan 55 HST, berpengaruh nyata terhadap berat buah dan berpengaruh tidak nyata terhadap panjang tanaman umur 15, 30, 45 dan 55 HST, jumlah daun tanaman berumur 15 HST dan umur tanaman berbunga. Interaksi yang terbaik dijumpai pada dosis pupuk NPK $160 \mathrm{~g} /$ tanaman dengan pemangkasan tunas lateral.

\section{DAFTAR PUSTAKA}

Dewani, M. 2000. Pengaruh pemangkasan terhadap pertumbuhan dan hasil tanaman kacang hijau (Vigna rediata L.) varietas Walet dan Wongsorejo. J Agrista. 01(12):18-23.

Harjadi, S. S., W. D. Winarno dan S. Ketty. 2010. Aspek-Aspek Penting Budidaya Tanaman Buah-Buahan. Dihimpun oleh G. A. Wattimena.

Hasibuan, B.E. 2006. Pupuk Dan Pemupukan. USU Press, Medan.

Jasmine, H. Q. F. C. P., J. Ginting., B. Siagian. 2015. Respon pertumbuhan dan produksi semangka (Citrullus vulgaris Schard.) terhadap konsentrasi puclobutrazol dan dosis pupuk NPK. Jurnal Online Agroteknologi. 2(3): 967-974

Junaidi., Imam., S, J, Santosa dan E, S, Sudalmi. 2013. Pengaruh macam mulsa dan pemangkasan terhadap pertumbuhan dan hasil tanaman semangka (Citrullus vulgaris Schard.). Jurnal Inovasi Pertanian 2(2): 67-69.

Rahim, I dan Sukarni. 2011. Pertumbuhan dan produksi melon pada dua jenis bokashi dan berbagai konsentrasi pupuk organik cair. Jurnal Agronomika. 1(2):87-91.

Susiani. 2003. Pengaruh dosis pupuk NPK dan toping terhadap terhadap pertumbuhan dan hasil tanaman labu mie (Cucurbita pepo L.). Jurnal Hortikultura. 15(02):21-26.

Sutedjo, M dan A. G. Kartasapoetra. 2002. Pupuk dan Cara Pemupukannya. Rineka Cipta, Jakarta.

Suwahyono dan Untung. 2011. Petunjuk Praktis Penggunaan Pupuk Organik Secara Efektif dan Efesien. Penebar Swadaya, Jakarta.

Syah, M., H. Yetti., S. Yoseva. 2016. Pengaruh pemberian bokashi dan NPK terhadap pertumbuhan dan produksi tanaman semangka (Citrullus vulgaris Schard.). Jom Faperta. 3(2):(1-10)

Tripama, B. 2009. Pengaruh pemangkasan cabang dan pengolahan tanah coklakan terhadap produksi tanaman semangka (Citrullus vulgaris Schard.) varietas Black sweet dengan sistem tanam baris ganda. Fakultas Pertanian, Universitas Muhammadiah Jember.

Wartapa, A. 2009. Pengaturan jumlah cabang utama dan penjarangan buah terhadap hasil dan mutu benih tomat varietas Kaliurang (Lycopersicum esculentum Mill.). Jurnal Ilmu Pertanian 5(2): 150-163. 